\title{
STUDI EKSPLORATIF PERILAKU BELAJAR SISWA DI KELAS V SEKOLAH DASAR
}

\section{EXPLORATIVE STUDY OF STUDENTS' LEARNING BEHAVIOR IN CLASS V OF ELEMENTARY SCHOOL}

\author{
Muhammad Ilham ${ }^{1}$, Waode Eti Hardiyanti ${ }^{2}$, Raehang ${ }^{3}$, Selin Titania ${ }^{4}$ \\ ${ }^{1,3,4}$ Pendidikan Guru Madrasah Ibtidaiyah IAIN Kendari, \\ ${ }^{2}$ Pendidikan Guru Pendidikan Anak Usia Dini Universitas Negeri Gorontalo \\ 1,3,4Jl. Sultan Qaimuddin No. 17 Baruga Kendari, (0401) 3193710/3193710, \\ ${ }^{2}$ Jl. Jend. Sudirman No.6, Dulalowo Tim., Kota Tengah, Kota Gorontalo, Gorontalo 96128 \\ Email: muhammadilham@iainkendari.ac.id ${ }^{1}$, waode@ung.ac.id ${ }^{2}$, \\ asrafraehang@gmail.com ${ }^{3}, \underline{\text { salintitania@gmail.com }}^{4}$
}

Submitted: 23-10-2021, Revised: 26-11-2021, Accepted: 29-11-2021

\begin{abstract}
Abstrak
Penelitian ini bertujuan untuk mengkaji perilaku belajar siswa kelas V SDN 92 Kendari dan upaya guru dalam meningkatkan perilaku belajar siswa. Studi ini menggunakan metode deskriptif kualitatif. Prosedur pengumpulan data terdiri dari wawancara, observasi, dan dokumentasi yang selanjutnya dianalisis dengan cara reduksi data, penyajian data, dan penarikan kesimpulan. Pengecekan keabsahan data dilakukan dengan triangulasi teknik dan sumber. Hasil penelitian menunjukkan bahwa perilaku belajar siswa sangat beragam. Sebagian siswa menunjukkan perilaku baik saat di kelas seperti mendengarkan guru dengan antusias, disiplin mengerjakan tugas yang diberikan, disiplin terhadap waktu dan tidak mengganggu teman saat belajar. Terdapat pula siswa berperilaku kurang baik seperti sering keluar masuk ruangan, mengabaikan instruksi guru, dan melanggar peraturan kelas. Upaya yang dilakukan oleh guru dalam meningkatkan perilaku belajar positif siswa kelas V SD Negeri 92 Kendari yaitu melakukan variasi dalam pembelajaran, aktif memberikan nasehat kepada siswa, dan memberikan hukuman kepada siswa berupa tugas tambahan.
\end{abstract}

Kata Kunci: Perilaku Belajar Siswa, Upaya Guru, Sekolah Dasar

\begin{abstract}
This research aims to examine the learning behavior of the fifth-grade students at SDN 92 Kendari and the teachers' efforts to improve their learning behavior. This study used a qualitative descriptive method. The procedure of collecting data was through interviews, observations, and documentation. Then, the data were analyzed employing data reduction, presentation, and conclusion. The triangulation techniques and sources were used to check the validity of the data. The results indicated that students' learning behavior was very diverse. Several students showed good behavior in class, such as listening to the teacher enthusiastically, being disciplined in doing the assigned tasks, being disciplined about time, and not disturbing friends while studying. However, some students behaved poorly, such as frequently going in and out of the room, ignoring the teachers' instructions, and violating class rules. Efforts made by the teachers to improve the learning behavior of the fifth-grade students at $S D$ Negeri 92 Kendari were doing variations in learning, actively advising students, and giving punishment to students in the form of additional assignments.
\end{abstract}

Keywords: Student Learning Behavior, Teachers' Efforts, Elementary School

How to Cite: Ilham, M., Hardiyanti, W. E., Raehang, \& Titania, S. (2021). Studi Eksploratif Perilaku Belajar Siswa di Kelas V Sekolah Dasar. AULADUNA: Jurnal Pendidikan Dasar Islam, 8(2), 202-215. 


\section{Pendahuluan}

Perilaku belajar merupakan sikap yang ditunjukkan siswa selama proses pembelajaran sebagai respon dari pembelajaran yang dilakukan guru di kelas. Perilaku belajar siswa dapat bernilai positif dan negatif. Munculnya perbedaan perilaku belajar tersebut sangat dipengaruhi oleh cara guru dalam memberikan pembelajaran di kelas. Guru dengan kemampuan mengajar yang baik akan menciptakan suasana akademik kelas yang menyenangkan bagi siswa. Guru yang memiliki kemampuan mengajar sangat buruk akan membuat suasana belajar di kelas menjadi tidak kondusif. Safitri \& Sontani (2016) menyatakan bahwa keterampilan mengajar guru dan motivasi belajar siswa berkorelasi kuat terhadap peningkatan hasil belajar siswa di kelas. Hal ini juga sejalan dengan Rauf, Suarman, \& Kartikowati (2020) yang menyatakan bahwa perilaku belajar siswa dapat mempengaruhi hasil belajarnya.

Perilaku belajar siswa merupakan indikator dari berjalan tidaknya strategi dan metode pembelajaran yang diterapkan guru di kelas. Perilaku belajar yang positif akan membuat guru menjadi termotivasi untuk terus menerapkan metode pembelajaran tersebut, namun jika perilaku belajar siswa bernilai negatif, maka guru perlu melakukan evaluasi perbaikan pembelajaran di kelas dan mencari solusi yang tepat untuk mengatasi masalah yang terjadi. Widiyani (2016) mengemukakan bahwa salah satu indikator keberhasilan pembelajaran adalah respon yang diberikan siswa saat pembelajaran berlangsung. Saat respon siswa bernilai positif, maka pembelajaran yang dilakukan berhasil, namun jika respon siswa bernilai negatif, maka pembelajaran perlu ditinjau kembali. Respon siswa yang dimaksud adalah perilaku belajar siswa yang terlihat selama kegiatan belajar berlangsung.

Terbentuknya karakter siswa dalam berperilaku saat belajar tidak terjadi dalam waktu yang singkat, tetapi membutuhkan waktu yang begitu lama. Perilaku belajar ini akan menjadi sikap dan tabiat siswa yang akan terus ditunjukkan saat mendapat stimulus tindakan tertentu dari guru. Soffatunni'mah \& Thomas (2017) mengemukakan bahwa perilaku belajar merupakan kebiasaan belajar yang dilakukan individu secara berulang-ulang, sehingga menjadi karakter yang melekat pada diri siswa.

Hasil observasi awal di SDN 92 Kendari menunjukkan bahwa banyak siswa yang memiliki perilaku kurang baik saat proses belajar berlangsung. Ada siswa yang menganggu temannya, tidak fokus, dan sering keluar masuk ruangan saat proses belajar, sehingga prestasi belajar siswa pun sangat jauh dari harapan karena proses pembelajaran yang tidak begitu baik. Hasil wawancara terhadap guru mengungkapkan bahwa beberapa metode telah diterapkan untuk mengatasi perilaku negatif siswa saat pembelajaran. Salah satu cara yang dilakukan yaitu melakukan variasi saat mengajar. Hal ini dilakukan agar siswa tidak bosan dan selalu antusias mengikuti proses pembelajaran. Hasil penelitian Cica, Chotimah, \& Waluyati (2019) mengemukakan bahwa variasi mengajar berpengaruh positif pada peningkatan motivasi siswa dalam belajar. Keterangan dari salah seorang guru menyebutkan metode tersebut cukup efektif untuk membimbing siswa dalam belajar di kelas dan terlihat perubahan sikap siswa ke arah positif setelah diterapkan metode tersebut.

Beberapa studi telah dilakukan berkaitan dengan perilaku belajar siswa di sekolah seperti Mardiana (2012) yang mengkaji perilaku belajar siswa SMP di kelas IPS terpadu, Rahayu, Salim, \& Amrazi (2015) dengan fokus penelitiannya yaitu upaya dalam pembinaan perilaku belajar siswa SMA saat belajar sosiologi, dan Rahayu \& Susanto (2018) yang mengkaji tentang pengaruh kepemimpinan guru dan manajemen kelas terhadap perilaku belajar siswa di sekolah dasar. Berdasarkan penelitian tersebut, 
kajian tentang perilaku belajar siswa di sekolah dasar hanya berkisar pada hubungan antara manajemen kelas dan kepimpinan guru terhadap perilaku belajar siswa. Hubungan antara perilaku belajar siswa dan upaya guru dalam meningkatkan perilaku belajar siswa baru dilakukan di tingkat SMP dan SMA dan belum ada yang mengkaji bagaimana upaya guru dalam meningkatkan perilaku belajar siswa di sekolah dasar, sehingga hal ini menjadi fokus yang akan dikaji dalam penelitian ini.

\section{Metode Penelitian}

Studi ini merupakan penelitian deskriptif kualitatif. Lokasi penelitian dilakukan di SD Negeri 92 Kendari. Subjek penelitian ini adalah 2 orang guru, 3 orang tua siswa, dan 21 siswa yang duduk pada kelas $\mathrm{V}$ sekolah dasar. Teknik pengumpulan data dilakukan dengan observasi, wawancara, dan dokumentasi. Observasi dilakukan untuk melihat bagaimana perilaku siswa saat belajar di kelas dan respon guru terhadap perilaku siswa tersebut. Wawancara digunakan untuk menggali lebih mendalam mengenai respon guru yang teramati oleh peneliti. Wawancara juga digunakan untuk menggali informasi kepada orang tua mengenai sikap dan perilaku siswa. Dokumentasi digunakan untuk mencari data pendukung baik itu berupa foto, catatan guru, dan catatan orang tua mengenai perilaku siswa saat belajar dan upaya yang dilakukan guru dalam merespon perilaku siswa tersebut.

Data kemudian dianalisis dengan prosedur pengumpulan data yakni data mengenai perilaku belajar siswa baik itu negatif ataupun positif dan upaya guru dalam peningkatan perilaku belajar siswa dikumpulkan menjadi satu kesatuan data yang saling terkait satu sama lain. Data tersebut kemudian direduksi, yaitu memilah data yang paling sesuai dengan tujuan penelitian. Data hasil reduksi kemudian disajikan dalam bentuk diagram dan kalimat yang mudah dimengerti. Terakhir, data tersebut diverifikasi untuk mencari hubungan dari perilaku belajar siswa dan upaya guru dalam peningkatan perilaku belajar siswa sampai pada pencapaian sebuah kesimpulan. Data diuji keabsahannya dengan cara triangulasi teknik yaitu proses penyesuaian data yang dikumpulkan dari berbagai teknik pengumpalan data (observasi, wawancara, dan dokumentasi) dan triangulasi sumber yaitu penyesuaian data perilaku belajar siswa dan upaya guru dalam meningkatkan perilaku belajar siswa berdasarkan hasil wawancara dari beberapa sumber informan.

\section{Hasil dan Pembahasan}

\subsection{Hasil}

\subsubsection{Perilaku Belajar Siswa di Sekolah}

Secara umum perilaku belajar siswa SDN 92 Kendari tidak jauh berbeda dengan perilaku belajar siswa sekolah lainnya yang sedang memasuki tahap pubertas, sehingga pembentukan perilaku belajar siswa sangat dipengaruhi oleh kemajuan teknologi dan faktor lingkungan baik lingkungan keluarga, teman, maupun masyarakat. Perilaku belajar siswa di lingkungan sekolah diekspresikan dalam bentuk interaksi kepada teman maupun guru yang teramati selama proses penelitian. Perilaku belajar siswa terdiri atas perilaku belajar positif dan perilaku belajar negatif. 


\subsubsection{Perilaku Belajar Positif Siswa}

Karakter seseorang dapat dilihat dari perilaku yang ditunjukkan saat berinteraksi kepada orang lain. Saat melakukan observasi, beberapa perilaku belajar positif siswa yang teramati adalah sebagai berikut:

\subsection{Disiplin dalam Penyelesaian Tugas}

Saat proses pembelajaran terjadi, siswa terkadang mendapatkan tugas mandiri dan kelompok untuk dikerjakan dan diselesaikan dalam kurun waktu tertentu selama proses belajar mengajar berlangsung. Meskipun beberapa siswa terkadang terlihat kurang bersemangat mendapat tugas dari guru dan bahkan melakukan protes terhadap gurunya, tetapi siswa tetap menyelesaikan pekerjaan tersebut sesuai dengan waktu yang ditentukan. Kutipan wawancara dari salah seorang guru mengungkapkan sebagai berikut:

"Dalam pembelajaran perilaku siswa sangat beragam. Beberapa siswa memiliki perilaku baik saat belajar. Saat mereka diberikan tugas mereka mendengarkan arahan dari guru, sehingga tugas mereka kumpulkan tepat waktu" (Ririn, 22 Maret 2021).

\subsection{Disiplin terhadap Waktu Belajar}

Kedisiplinan siswa tidak hanya dalam pengumpulan tugas, tetapi juga pada waktu kehadiran di sekolah. Berdasarkan pengamatan yang dilakukan peneliti, hampir semua siswa masuk ke kelas tepat waktu, saat belajar dimulai hanya satu sampai dua kursi yang terkadang tidak terisi. Ketidakhadiran siswa di kelas karena alasan kesehatan dan sudah meminta izin kepada wali kelas melalui surat yang dikirimkan orang tua siswa ke sekolah. Kutipan wawancara dari salah seorang guru juga mengindikasikan hal yang serupa yakni sebagai berikut:

"Beberapa siswa menaati peraturan saat di kelas atau pada saat sedang melakukan pembelajaran. Beberapa siswa sering tepat waktu pada saat masuk kelas, sehingga membuat mereka mengikuti arahan dari awal masuk ruangan (Pipiati, 8 April 2021)".

\subsection{Antusias pada Penjelasan Guru}

Perilaku belajar positif lain yang ditunjukkan siswa saat mengikuti pembelajaran adalah siswa antusias dan fokus mendengarkan pemaparan dan penjalasan dari guru berkaitan dengan bahan ajar. Perilaku antusias siswa dapat dilihat dari kecenderungan siswa untuk merespon pertanyaan dari guru dengan cepat, membantu teman yang tidak bisa menjawab pertanyaan saat diminta oleh guru, dan aktif mengemukakan pendapat kepada guru itu sendiri. Berikut kutipan wawancaranya.

"Saat belajar siswa mendengarkan gurunya menjelaskan di depan kelas dengan baik, sehingga saat diberikan soal mereka mengerjakannya dengan begitu tenang tanpa merasa gelisah" (Rina, 25 maret 2021).

\subsection{Tertib dalam Belajar}

Perilaku belajar positif berikutnya yang ditunjukkan siswa saat belajar di kelas adalah tidak membuat keributan atau mengganggu teman sekelasnya. Saat proses pembelajaran berlangsung, terlihat secara sepintas bahwa kelas dalam keadaan ribut. 
Tetapi, keributan yang terjadi karena adanya siswa yang saling berdebat satu sama lain dalam menjawab pertanyaan dari guru. Saat guru memberikan arahan untuk tidak terlalu keras dalam berbicara, siswa langsung mengindahkan instruksi dari guru. Siswa juga terlihat saling menghormati satu sama lain dan tidak mengganggu teman lainnya yang sedang sibuk mengerjakan tugas individu. Berikut kutipan wawancaranya.

"Melihat perilaku belajar siswa yang sangat beragam perilaku yang baik yang dilakukan oleh siswa yaitu fokus pada saat pembelajaran sehingga kelas menjadi tenang tanpa ada yang menganggu temannya" (Wartin, 3 April 2021).

\subsubsection{Perilaku Belajar Negatif Siswa}

Saat pembelajaran berlangsung, perilaku yang diperlihatkan siswa tidak hanya yang bernilai positif, tetapi terdapat pula beberapa perilaku siswa yang dikategorikan perilaku negatif bahkan mengganggu jalannya proses pembelajaran. Beberapa perilaku negatif siswa antara lain:

\subsection{Keluar Masuk Ruangan saat Pembelajaran}

Salah satu perilaku belajar siswa yang bernilai negatif adalah kecenderungan siswa untuk selalu keluar masuk ruangan saat pembelajaran berlangsung. Perilaku tersebut dilakukan oleh sebagian besar siswa dengan berbagai alasan tertentu. Ada yang keluar dengan alasan ke toilet dan sebagian siswa menggunakan alasan membuang ludah atau kotoran yang ada di hidung. Perilaku ini tidak hanya dilakukan oleh siswa laki-laki, tetapi pula oleh siswa perempuan dan dilakukan secara berulang-ulang. Berikut kutipan wawancaranya.

"Perilaku belajar siswa sangat beragam, ada yang menaati peraturan dalam kelas saat belajar dan ada juga yang tidak menaati peraturan yang ada. Seperti, keluar masuk kelas saat belajar dengan alasan izin ke toilet, membuang kotoran di hidung, dan lain-lain. Di lain waktu, mereka mengulangi kesalahan yang sama" (Rina, 25 Maret 2021).

\subsection{Mengabaikan Instruksi Guru}

Guru tidak hanya menjelaskan materi pelajaran, namun sering kali guru menginstruksikan siswa untuk melakukan pembelajaran mandiri seperti diskusi kelompok atau mengerjakan beberapa kuis yang ada dalam buku yang telah dibagikan oleh guru. Terlihat bahwa banyak instruksi yang diberikan guru tidak dikerjakan siswa seperti siswa diminta menjawab pertanyaan pada soal tertentu, namun siswa tidak memberikan respon dan hanya diam menunggu guru mengalihkan pertanyaan tersebut ke siswa lainnya. Berikut kutipan wawancara dengan salah satu guru menguatkan pengamatan yang dilakukan peneliti.

"Saat di ruangan ada beberapa siswa saat disuruh menulis materi mereka tidak mengerjakannya, sehingga saat diberi tugas mereka tidak tahu menjawabnya. Perilaku yang seperti itulah harus dipertegas kembali dengan memberikan nasehat kepada mereka dampak dari kemalasan siswa itu sendiri" (Sitti Murni, 3 Mei 2021). 


\subsection{Siswa Melanggar Aturan yang telah Dibuat di Kelas}

Demi tertibnya kegiatan belajar di kelas, guru membuat peraturan-peraturan yang harus ditaati siswa di kelas. Peraturan tersebut sifatnya mengikat dan jika dilanggar, maka siswa akan diberi teguran bahkan hukuman. Terlihat beberapa siswa masih sering melanggar peraturan yang ada seperti ribut di kelas, mengganggu temannya, dan mengotori ruangan kelas. Hal ini mengakibatkan kegiatan belajar mengajar terganggu dan siswa yang lain merasa tidak nyaman untuk belajar di kelas. Berikut kutipan wawancara dengan salah satu guru.

“...... Siswa sering melanggar aturan pada saat belajar seperti mengganggu teman lainnya yang sedang fokus belajar dan kadang tidak mengerjakan tugas rumah dengan alasan lupa. Perilaku belajar seperti itu yang sering terjadi" (Wartin, 3 April 2021).

\subsubsection{Upaya Guru dalam Meningkatkan Perilaku Belajar Siswa di Sekolah}

Peningkatan perilaku belajar siswa di kelas merupakan upaya yang dilakukan guru untuk mempertahankan perilaku belajar siswa yang sudah baik dan mengubah perilaku belajar negatif siswa menjadi perilaku yang bernilai positif, sehingga dapat mendukung kelancaran proses pembelajaran dan sekaligus meningkatkan pemahaman siswa akan materi yang sedang dipelajari.

\subsubsection{Perilaku Belajar Positif Siswa}

Beberapa perilaku belajar positif yang ditunjukkan siswa saat belajar di kelas, antara lain: (1) disiplin dalam penyelesain tugas, (2) disiplin terhadap waktu belajar, (3) antusias mendengarkan penjelasan guru, dan (4) tertib dalam mengikuti pembelajaran. Beberapa tindakan yang diambil guru dalam upaya menjaga agar perilaku-perilaku tersebut tetap ditunjukkan siswa saat belajar, diantaranya:

\subsection{Pemberian Motivasi dan Dorongan untuk Selalu Berprestasi}

Keterangan dari salah seorang guru menyebutkan tindakan ini dianggap cukup efektif karena akan masuk ke aspek spiritual siswa yang paling dalam, sehingga siswa dengan sendirinya akan mempertahankan perilaku belajar positif tersebut. Siswa juga akan merasa sebagai mahluk individu yang dihargai oleh gurunya sendiri. Salah seorang informan mengungkapkan:

"Upaya seorang guru dalam meningkatkan perilaku siswa terutama pada saat pembelajaran yaitu dengan memberikan semangat kepada siswa yang perilakunya baik dalam belajarnya agar dapat dipertahankan bahkan lebih ditingkatkan lagi. Seperti, perilaku saat mengumpulkan tugas dengan tepat waktu" (Aprilia, 22 Maret 2021).

Keterangan dari salah satu guru menyebutkan pemberian motivasi dan dorongan untuk selalu berprestasi sangat cocok untuk diterapkan dalam mempertahankan sikap disiplin siswa terhadap penyelesaian tugas dan waktu belajar di kelas.

\subsection{Pemberian Variasi dalam Mengajar}

Penerapan metode dan teknik pembelajaran yang beraneka ragam merupakan salah satu cara yang dilakukan guru dalam menjaga sikap belajar positif siswa di kelas. Penggunaan variasi metode pembelajaran membuat siswa tidak cepat bosan atau jenuh 
mengikuti pembelajaran, tetapi siswa malah menjadi senang dan tertantang untuk memecahkan masalah pembelajaran selanjutnya. Berikut keterangan dari salah satu guru.

"Berbagai cara yang dilakukan oleh seorang guru dalam meningkatkan perilaku belajar siswa yaitu salah satunya dengan melakukan variasi dalam mengajar agar siswa lebih bersemangat dalam belajarnya dan tidak melakukan kesalahan, seperti keluar masuk ruangan dikarenakan bosan" (Rina, 25 Maret 2021).

Pemaparan lanjut dari guru menyebutkan variasi metode pembelajaran sangat cocok diimplementasikan untuk perilaku siswa yang tidak membuat keributan saat belajar. Hal ini dikarenakan siswa fokus terhadap cara guru dalam menyampaikan pembelajaran dan keinginan untuk mengganggu teman atau membuat kegaduhan tidak ada.

\subsection{Menyelingi Kuis Berhadiah saat Pembelajaran Berlangsung}

Memasukan unsur kuis merupakan salah satu strategi yang dilakukan guru untuk menghidupkan suasana kelas agar pembelajaran dapat menyenangkan, sehingga siswa dapat antusias untuk mengikut pembelajaran ini. Berikut kutipan wawancaranya.

"Upaya yang dilakukan guru untuk perilaku belajar yang baik dalam kelas pada saat belajar adalah dengan melakukan pembelajaran dengan memasukan kuis lalu diberikan reward dengan tujuan agar siswa dapat fokus pada pembelajarannya dan tidak melakukan aktifitas tambahan yang mengandung unsur melanggar peraturan" (Pipit, 8 April 2021).

\subsubsection{Perilaku Belajar Negatif Siswa}

Beberapa perilaku negatif siswa yang terlihat saat pembelajaran di kelas, antara lain: (1) sering keluar masuk kelas, (2) mengabaikan instruksi yang diberikan guru, dan (3) melanggar aturan kelas yang telah ditetapkan. Perilaku belajar negatif siswa tersebut perlu diatasi agar pembelajaran di kelas berjalan dengan baik. Beberapa upaya yang telah dilakukan guru dalam mengatasi perilaku belajar negatif siswa adalah sebagai berikut:

\subsection{Memberikan Teguran dan Nasihat}

Salah satu cara yang dilakukan guru di kelas saat siswa sering keluar masuk ruangan adalah dengan memberikan teguran kepada siswa. Teguran dilakukan dengan memberikan pertanyaan langsung tentang maksud dan tujuan dari siswa keluar ruangan. Jika maksud siswa tidak terlalu signifikan, maka siswa akan dilarang untuk keluar, namun bila tujuannya penting, maka siswa akan diberikan izin dengan batasan waktu yang telah ditentukan. Berikut kutipan wawancaranya.

"Berbagai cara yang dilakukan oleh guru dalam meningkatkan perilaku belajar siswa yaitu salah satunya mempertegas peraturan di kelas dan memberi teguran kepada siswa yang melanggar" (Rina, 25 maret 2021).

Setelah siswa diberi teguran, guru langsung memberikan nasihat kepada siswa. Nasihat yang diberikan mengandung pesan agar siswa fokus dalam belajar dan tidak terganggu dengan apa yang terjadi di luar kelas. Guru juga mengaitkan nasihat yang 
diberikan dengan tujuan dan cita-cita dari siswa dengan keseriusan siswa dalam belajar, sehingga siswa menjadi lebih paham dan menyadari pentingnya materi yang sedang dipelajari. Berikut kutipan wawancaranya.

"Upaya seorang guru dalam meningkatkan perilaku belajar yang tidak baik kepada siswa terutama pada saat pembelajaran yaitu dengan memberikan nasehat kepada siswa yang perilakunya tidak baik dalam belajarnya agar dapat berubah menjadi lebih baik lagi” (Aprilia, 22 Maret 2021).

\subsection{Memberikan Hukuman Mendidik}

Pemberian hukuman berupa membersihkan toilet, halaman sekolah, atau memberikan tugas tambahan merupakan salah satu cara yang dilakukan guru untuk mengurangi perilaku negatif siswa yang sering melanggar aturan di kelas. Meskipuan tidak sering, saat pembelajaran terjadi, siswa terkadang mengganggu teman di sampingnya, sehingga menimbulkan keributan. Guru langsung menegur dengan memberikan hukuman mendidik untuk mengurangi perilaku ini. Berikut kutipan wawancaranya.

"Upaya yang dilakukan untuk mengatasi adanya perilaku belajar yang tidak baik dalam kelas pada saat belajar adalah dengan memberikan teguran terus menerus. Jika teguran tidak didengarkan, maka guru melakukan hukuman".

\subsection{Menggunakan Metode Pembelajaran yang Berbeda untuk Setiap Pertemuan}

Metode pembelajaran yang digunakan guru diubah untuk setiap pertemuan. Ini dilakukan dengan tujuan siswa tidak bosan dalam mengikuti pembelajaran di kelas dan siswa merasa penasaran dengan kegiatan belajar yang akan dilakukan. Tentunya keadaan ini berdampak pada keseriusan siswa di kelas untuk melaksanakan semua instruksi yang diberikan guru. Berikut kutipan wawancaranya.

"Upaya yang dilakukan yaitu mengubah cara belajar yang tadinya hanya sekedar menjelaskan menjadi tanya jawab dengan begitu siswa yang perilaku belajarnya kurang baik dapat terfokus apa yang guru jelaskan, sehingga membuat aktifitas sedikit berkurang" (Tini, 8 April 2021).

\subsection{Pembahasan}

\subsubsection{Perilaku Belajar Siswa di Sekolah}

Perilaku belajar siswa yang merupakan respons dari pembelajaran yang diberikan guru di kelas sangat beragam. Perilaku belajar siswa tersebut ada yang bernilai negatif dan ada pula yang bernilai positif. Dikatakan positif bila perilaku yang ditunjukkan siswa tersebut dapat mendukung terlaksananya pembelajaran yang aktif dan menyenangkan di kelas. Namun bila perilaku belajar tersebut menghambat ketercapaian tujuan pembelajaran yang telah ditetapkan maka perilaku belajar siswa tersebut bernilai negatif.

\subsubsection{Perilaku Belajar Positif Siswa}

Beberapa perilaku belajar positif siswa yang terlihat dalam penelitian ini yaitu: 


\subsection{Siswa Selalu Disiplin dalam Penyelesaian Tugas dan Waktu Belajar}

Siswa kelas V SDN 92 Kendari telah menunjukkan kedisipilinan mereka dalam mengerjakan tugas, baik secara individu maupun kelompok selama pembelajaran berlangsung. Kedisiplinan siswa dapat dilihat dari kepatuhan siswa dalam menyelesaikan tugas belajar sebelum waktu yang ditentukan oleh guru. Siswa pula selalu tepat waktu saat masuk ke sekolah atau masuk ke kelas. Sikap kedisiplinan terbentuk karena pembiasaan yang telah dilakukan oleh warga sekolah dalam hal ini guru maupun kepala sekolah. Rutinitas yang dilakukan setiap hari untuk tepat waktu dalam menjalankan setiap aktivitas di sekolah membentuk karakter siswa itu sendiri. Marwiyati (2020) mengungkapkan pembiasaan merupakan salah satu cara yang paling efektif untuk membentuk sikap dan perilaku perserta didik di sekolah.

Guru juga di sekolah selalu memotivasi anak untuk mengembangkan diri menuju arah yang lebih baik untuk membentuk sikap disiplin siswa. Motivasi merupakan dorongan kepada diri seseorang, baik yang muncul dari dalam diri atau dari orang lain untuk melakukan sesuatu demi tercapainya hal yang diinginkan. Arianti (2010) menyatakan bahwa motivasi merupakan kondisi psikologis yang mendorong seseorang untuk melakukan sesuatu. Idzhar (2016) menyatakan bahwa motivasi dipandang sebagai dorongan mental yang menggerakkan dan mengarahkan prilaku manusia termasuk prilaku belajar. Jadi, dapat disimpulkan bahwa motivasi menjadi faktor utama seseorang akan bertindak dan berperilaku sesuai dengan tujuan yang hendak dicapai.

Motivasi sendiri terdiri atas dua yaitu motivasi internal dan motivasi eksternal. Jika motivasi eksternal berasal dari luar baik itu berupa nasihat, dorongan, semangat, maupun pengaruh, maka motivasi internal berasal dari dalam diri seseorang yang telah ada dan tinggal membutuhkan pengembangan (Sardiman dalam Djarwo, 2020). Agar siswa memiliki motivasi yang tinggi dalam belajar, maka faktor internal yang merupakan potensi yang dimiliki siswa seperti intelegensi, minat, bakat, dan emosi perlu diperkuat guru melalui stimulus dan dorongan. Hal ini dilakukan agar siswa sadar dengan tujuan dan cita-cita serta menggunakan seluruh potensi yang dimilikinya untuk mengembangkan diri.

Saat memiliki motivasi tinggi dalam belajar, maka secara sadar siswa akan melakukan hal-hal yang dapat mendukung anak tersebut sukses dalam belajarnya, termasuk menanamkan sikap disiplin dalam waktu penyerahan tugas rumah dan kehadiran di sekolah. Djarwo (2020) mengemukakan bahwa seorang anak yang sudah memiliki motivasi untuk melakukan sesuatu, akan berusaha mengerjakannya dengan baik dan tekun dengan harapan memperoleh hasil yang baik. Sulthon (2015) mengemukakan bahwa guru harus selalu menanamkan nilai-nilai kehidupan ke depan yang lebih progresif dengan alasan apa yang akan dihadapi siswa di masa yang akan datang tentunya akan lebih sulit dibanding dengan saat ini.

\subsection{Siswa Antusias Mendengarkan Penjelasan Guru dan Tidak Gaduh saat Mengikuti Pelajaran}

Perilaku positif lain yang ditunjukkan siswa saat belajar adalah sikap antusias dan tidak membuat keributan saat belajar. Antusias dalam belajar dapat ditunjukkan siswa di kelas jika pembelajaran yang dilaksanakan sangat menarik, memotivasi, dan memacu siswa untuk bekerja keras dalam memecahkan permasalahan pembelajaran yang dihadapi. Pembentukan suasana akademik tersebut membutuhkan kreativitas yang lebih dari guru dalam menciptkan pembelajaran yang baik. Guru perlu membuat pembelajaran yang bervariasi dan tidak menonton, sehingga siswa pada setiap kelas 
akan terus penasaran dengan pembelajaran yang akan dilakukan. Hasil peneltian Santosa (2017) menunjukkan bahwa pembelajaran dengan model baru akan meningkatkan antusiasme siswa dalam belajar.

Kejenuhan siswa dalam kegiatan pembelajaran merupakan masalah yang pada umumnya dihadapi guru di kelas. Terjadinya perilaku siswa ini diakibatkan oleh banyak faktor, bisa dari suasana kelas, sarana dan prasarana, siswa itu sendiri, dan dari guru, serta metode yang diterapkannya. Namun, di antara faktor yang paling besar pengaruhnya terhadap kejenuhan siswa adalah guru itu sendiri. Sulthon (2015) menyatakan guru adalah agen pembelajaran, siswa tidak akan pernah belajar dengan baik dengan tanpa bantuan dan bimbingan guru di sekolah.

Menyadari hal tersebut, maka seyogianya dalam pembelajaran perlu ada inovasi dan gebrakan baru yang diberikan guru. Pembelajaran yang kreatif dan menyenangkan serta dengan beberapa variasi menjadi alternatif yang paling baik agar antusias siswa dalam belajar menjadi tinggi, yang tentunya akan berdampak positif pada peningkatan prestasi belajar siswa di kelas. Rahmawati \& Hasanah (2021) menyatakan bahwa seorang guru harus memiliki kreativitas dalam mengajar agar tujuan pembelajaran yang ditetapkan dapat tercapai dengan maksimal. Anam \& Yahya (2021) mengungkapkan bahwa guru dituntut untuk aktif, kreatif, dan inovatif, agar siswa tidak merasa bosan dalam belajar.

\subsubsection{Perilaku Belajar Negatif Siswa}

Hasil penelitian menunjukkan beberapa perilaku yang bernilai negatif yang dilakukan siswa selama pembelajaran yaitu:

\subsection{Siswa Sering Keluar Masuk Ruangan saat Pembelajaran Dilaksanakan}

Salah satu indikator yang menunjukkan siswa bosan mengikuti pembelajaran adalah kecenderungan siswa untuk keluar masuk ruangan saat pembelajaran dilakukan. Keluar masuknya siswa yang dimaksud adalah keadaan siswa selalu meminta izin kepada guru untuk keluar ruangan saat pembelajaran dilaksanakan dengan berbagai alasan. Hasil penelitian menunjukkan keluar masuknya siswa dikarenakan berbagai hal, antara lain buang air kecil, buang ludah, dan buang angin. Keterangan dari beberapa siswa menyebutkan bahwa keluarnya siswa dari ruangan saat pembelajaran tidak murni dikarenakan alasan ke kamar kecil, tetapi untuk sekadar melihat-lihat keluar atau menggerakkan badan setelah duduk lama di kelas. Dari alasan siswa, terlihat bahwa perilaku tersebut mengindikasikan adanya kejenuhan siswa di kelas baik karena materi yang tidak dimengerti atau karena model pembelajaran yang dilakukan guru. Damayanti, Suradika, \& Asmas (2020) mengungkapkan bahwa terdapat beberapa faktor yang menyebabkan kejenuhan siswa di kelas yaitu metode, guru yang tidak disenangi siswa, terlalu banyak tugas, dan faktor yang lain.

Berdasarkan keterangan dari salah seorang guru untuk mengurangi keseringan munculnya perilaku tersebut, maka guru yang mengajar saat itu memberikan teguran dan nasihat kepada siswa. Teguran kepada siswa diyakini sebagai cara yang paling sesuai untuk dilakukan di sekolah tersebut. Alasannya adalah mental siswa di sekolah tersebut yang sudah terbiasa jika tidak mendapatkan teguran akan tetap melanjutkan perilaku tersebut di kelas meskipun bernilai negatif. Keadaan ini juga sesuai dengan teori belajar behaviorisme yang menjelaskan tentang hukum operant conditioning yaitu jika suatu perilaku diberi penguatan, maka perilaku tersebut akan terus dilakukan, namun jika suatu perilaku yang ditunjukkan tidak diberi penguatan, maka perilaku tersebut akan menghilang operant extinction (Afandi \& Badarudin, 2011). Jadi, perilaku 
belajar siswa yang sering keluar masuk diberi teguran (penguatan), maka perilaku tersebut akan terjadi sesuai dengan apa yang diinginkan, namun jika tidak diberi teguran (penguatan), maka perilaku yang ditunjukkan siswa tidak sesuai dengan yang diinginkan.

\subsection{Siswa Mengabaikan Instruksi Guru dan Melanggar Peraturan Kelas}

Perilaku negatif lainnya yang ditunjukkan siswa saat melakukan pembelajaran yaitu banyak siswa yang mengabaikan instruksi guru dan melanggar peraturan kelas. Saat pembelajaran terjadi, komunikasi yang seharusnya dibangun oleh guru tidak hanya dalam model satu arah yaitu antara guru dan siswa, tetapi harus terdiri dari banyak arah yaitu antara guru dan siswa A, guru dan siswa B, siswa B dengan siswa A, dan seterusnya. Hal ini dilakukan dengan maksud agar kelas menjadi hidup dan dinamika pembelajaran dapat berjalan dengan baik. Gunawan, Putrayasa, \& Wendra (2017) mengemukakan bahwa guru dengan kemampuan komunikasi yang baik akan menghidupkan suasana kelas, sehingga transformasi pengetahuan dari guru ke siswa akan menjadi lebih mudah. Guru sangat berperan penting dalam pembentukan perilaku siswa. Guru harus menjadi panutan sekaligus pembimbing bagi siswa dalam mewujudkan perilaku yang berkarakter (Hidayah, 2020).

Perilaku mengabaikan instruksi guru dan melanggar peraturan kelas di sini yaitu ketidakmauan siswa untuk mengikuti dan melakukan seruan atau permintaan guru dan mengikuti aturan yang berlaku dalam proses pembelajaran. Perilaku ini mungkin terjadi karena dipengaruhi oleh beberapa hal diantaranya faktor yang berasal dari siswa sendiri, seperti faktor psikologis dan faktor yang berasal dari guru. Kesiapan siswa dalam belajar di kelas sangat erat kaitannya dengan faktor psikologis siswa itu sendiri. Siswa akan bersemangat belajar jika tidak ada hal yang mengganggu pikiran siswa di sekolah. Hal-hal yang dapat membuat siswa tidak semangat dalam belajar dapat berasal dari masalah keluarga yang tidak harmonis, lingkungan teman bermain yang tidak baik, dan juga faktor kesehatan siswa itu sendiri. Andriyani \& Suryani (2017) mengemukakan bahwa terdapat 6 faktor yang mempengaruhi kesiapan siswa dalam belajar yaitu faktor psikis, lingkungan sekolah, empati dari masyarakat, keterampilan sosial, jasmani, dan faktor kebutuhan siswa. Faktor yang berasal dari guru dapat berupa kepribadian dan perawakan guru di kelas, keterampilan sosial guru yang kurang baik, dan cara mengajar guru yang tidak menarik.

Hasil wawancara dari salah seorang guru menyebutkan bahwa masalah yang terjadi di kelas telah diberikan tindakan berupa penggunaan metode yang bervariasi dalam belajar. Cara ini terbukti cukup efektif untuk mengurangi perilaku siswa yang enggan melakukan instruksi dari guru di kelas. Hasil penelitian Khausar (2014) menunjukkan bahwa selain peningkatan prestasi belajar, penggunaan metode bervariasi dalam mengajar juga memininalisir perilaku belajar negatif siswa seperti tidur di kelas, ribut, dan tidak memperhatikan penjelasan guru.

Guru juga telah menerapkan pemberian hukuman kepada siswa. Pemberian hukuman diberikan jika tindakan siswa sudah melewati kewajaran berdasarkan pengamatan guru. Hukuman yang diberikan bernilai edukatif seperti membersihkan ruangan kelas, toilet, halaman sekolah, atau menghapal materi pelajaran tertentu. Hukuman tersebut akan membuat siswa menyadari bahwa tindakan yang dilakukannya adalah salah sekaligus belajar mengenai nilai kesabaran dalam menghadapi hal yang tidak mengenakkan bagi siswa. Anggraini, Siswanto, \& Sukamto (2019) menyatakan 
bahwa hukuman akan membuat siswa menyesali dan sadar bahwa perbuatan yang dilakukan adalah salah.

\section{Simpulan}

Perilaku belajar siswa saat mengikuti pembelajaran di kelas sangat beragam, ada yang bernilai positif tetapi terdapat pula yang bernilai negatif. Guru harus secara aktif dan berulang-ulang memberikan nasihat dan petuah kepada siswa untuk selalu berprestasi dalam belajar agar siswa berperilaku disiplin terhadap waktu dan deadline tugas yang diberikan, sehingga siswa dalam belajar memiliki tujuan dan cita-cita. Pemberian variasi metode pembelajaran disertai dengan kuis akan menarik perhatian siswa di kelas, sehingga siswa akan antusias dalam mengikuti pembelajaran dan tidak membuat keributan atau mengganggu teman kelasnya.

Siswa yang sering keluar masuk ruangan harus diberi teguran dan dinasehati untuk fokus dalam mengikuti pembelajaran. Nasihat yang diberikan harus membuat siswa menjadi sadar bahwa tindakan yang dilakukan tidak baik dan merugikan diri siswa sendiri. Saat perilaku siswa sudah melewati batas seperti tidak mengikuti instruksi guru atau melanggar peraturan yang ditetapkan di kelas, maka guru perlu melakukan evaluasi terhadap pembelajaran yang dilakukan apakah cara yang dilakukan sudah sesuai atau adakah faktor lain yang mempengaruhi perilaku belajar siswa seperti faktor psikis, keluarga, lingkungan kelas, dan sekolah. Pemberian hukuman mendidik perlu juga dilakukan agar siswa dapat mengambil pelajaran yang berharga untuk perbaikan dirinya ke depan.

\section{Daftar Pustaka}

Afandi, M., \& Badarudin. (2011). Perencanaan Pembelajaran di Sekolah Dasar dengan Memasukkan Pendidikan Budaya dan Karakter Bangsa (1st ed.). Alfabeta.

Anam, K., \& Yahya, M. S. (2021). Inovasi Guru dalam Pembelajaran Masa Pandemi Covid-19. JISIP (Jurnal Ilmu Sosial dan Pendidikan), 5(3), 8-15. https://doi.org/ 10.36312/jisip.v5i3.2090

Andriyani, W., \& Suryani, N. (2017). Faktor-Faktor yang Mempengaruhi Kesiapan Belajar Peserta Didik Kelas X Administrasi Perkantoran di SMK Negeri 1 Slawi Tahun Pelajaran 2015/2016. Economic Education Analysis Journal, 6(1), 218228. https://journal.unnes.ac.id/sju/index.php/eeaj/article/view/13487

Anggraini, S., Siswanto, J., \& Sukamto. (2019). Analisis Dampak Pemberian Reward and Punishment bagi Siswa SD Negeri Kaliwiru Semarang. Jurnal Mimbar PGSD Undiksha, 7(3), 221-229. https://doi.org/10.23887/jjpgsd.v7i3.19393

Arianti. (2018). Peranan Guru dalam Meningkatkan Motivasi Belajar Siswa. DIDAKTIKA: Jurnal Kependidikan, 12(2), 117-134. https://doi.org/10.30863/ didaktika.v12i2.181

Cica, M., Chotimah, U., \& Waluyati, S. A. (2019). Peningkatan Motivasi Belajar Siswa melalui Variasi Gaya Mengajar pada Mata Pelajaran PPKn. Bhineka Tunggal Ika: Kajian Teori dan Praktik PKn, 6(2), 232-237. https://doi.org/10.36706/ jbti.v6i 2.8800

Damayanti, A., Suradika, A., \& Asmas, T. B. (2020). Strategi Mengurangi Kejenuhan Anak dalam Pembelajaran Jarak Jauh (PJJ) melalui Aplikasi ICANDO pada Siswa Kelas I SDN Pondok Pinang 08 Pagi. Seminar Nasional Penelitian LPPM UMJ, 1-10. https://jurnal.umj.ac.id/index.php/semnaslit/article/view/7861 
Djarwo, C. F. (2020). Analisis Faktor Internal dan Eksternal terhadap Motivasi Belajar Kimia Siswa SMA Kota Jayapura. Jurnal Ilmiah IKIP Mataram, 7(1), 1-7. https://e-journal.undikma.ac.id/index.php/jiim/article/view/2790

Gunawan, I. K. G. W., Putrayasa, I. B., \& Wendra, I. W. (2017). Komunikasi Interpersonal Guru dan Siswa dalam Pembelajaran Teks Ulasan di Kelas VIII 10 SMP Negeri 2 Singaraja. E-Journal Prodi Pendidikan Bahasa dan Sastra Indonesia, 7(2), 1689-1699. https://doi.org/10.23887/jjpbs.v7i2.11278

Hidayah, U. (2020). The Role of the Teacher in Shapeing Student Learning Behavior in Arabic Learning. International Journal of Islamic Education, Research and Multiculturalism (IJIERM), 2(3), 178-186. https://doi.org/10.47006/IJIERM.V2 I3.42

Idzhar, A. (2016). Peranan Guru dalam Meningkatkan Motivasi Belajar Siswa. Jurnal Office, 2(2), 221-228. https://doi.org/10.26858/jo.v2i2.2956

Khausar. (2014). Pengaruh Penerapan Metode Pembelajaran Guru yang Bervariasi terhadap Peningkatan Hasil Belajar pada Siswa Kelas XI SMA Negeri 1 Labuhanhaji Timur Aceh Selatan. Jurnal Genta Mulia, 5(2), 72-85. https://ejournal.stkipbbm.ac.id/index.php/gm/article/view/67

Mardiana, N. (2012). Upaya Guru dalam Meningkatkan Perilaku Belajar Siswa Mata Pelajaran IPS Terpadu di SMP. Jurnal Pendidikan dan Pembelajaran Khatulistiwa, 1(1). https://jurnal.untan.ac.id/index.php/jpdpb/article/view/435

Marwiyati, S. (2020). Penanaman Pendidikan Karakter melalui Pembiasaan. ThufuLA: Jurnal Inovasi Pendidikan Guru Raudhatul Athfal, 8(2), 152-163. https://doi.org/10.21043/thufula.v8i2.7190

Rahayu, R., \& Susanto, R. (2018). Pengaruh Kepemimpinan Guru dan Keterampilan Manajemen Kelas terhadap Perilaku Belajar Siswa Kelas IV. Jurnal Pendidikan Dasar PerKhasa, 4(2), 220-229. https://doi.org/10.31932/jpdp.v4i2.178

Rahayu, S., Salim, I., \& Amrazi, Z. (2015). Peranan Guru dalam Membina Perilaku Belajar Siswa pada Proses Pembelajaran Sosiologi. Jurnal Pendidikan dan Pembelajaran Khatulistiwa, 7(1), 1-8. https://jurnal.untan.ac.id/index.php/jpdp b/article/view/23514

Rahmawati, P. N., \& Hasanah, E. (2021). Kreativitas dan Inovasi Guru dalam Pembuatan Materi Guru pada Masa Pandemi. Jurnal Administrasi Pendidikan, 28(1), 113-124. https://doi.org/10.17509/jap.v28i1.30009

Rauf, A., Suarman, S., \& Kartikowati, S. (2020). The Influence of Emotional Intelligence and Student Learning Behavior through Student Motivation on Student Learning Outcomes. Journal of Educational Sciences, 4(4), 881-889. https://doi.org/10.31258/JES.4.4.P.881-889

Safitri, E., \& Sontani, U. T. (2016). Keterampilan Mengajar dan Komunikasi Interpersonal Guru sebagai Determinan terhadap Motivasi Belajar Siswa. Jurnal Pendidikan Manajemen Perkantoran, 1(1), 144-153. https://doi.org/10.17509/ jpm.v1i1.3258

Santosa, D. S. S. (2017). Peningkatan Antusiasme dan Kedalaman Kajian Belajar Mahasiswa melalui Pembelajaran Berbasi Silabus Individual. Prosiding Seminar Nasional Hasil Penelitian dan Pengabdian Kepada Masyarakat II Univerisitas PGRI Roggowale Tuban, 2(1), 139-144. http://prosiding.unirow.ac.id/index.php/ SNasPPM/article/view/97

Soffatunni'mah, E., \& Thomas, P. (2017). Pengaruh Lingkungan Keluarga dan Motivasi Belajar terhadap Perilaku Belajar Siswa di Man 2 Semarang. Economic 
Education Analysis Journal, 6(2), 447-458. https://journal.unnes.ac.id/sju/index. php/eeaj/article/view/16435

Sulthon. (2015). Konsep Guru yang Menginspirasi dan Demokratif. Elementary, 3(1), 164-134. https://doi.org/10.21043/elementary.v3i1.1446

Widiyani, D. T. (2021). Indikator Pembelajaran Efektif dalam Pembelajaran Daring (Dalam Jaringan) pada Masa Pandemi Covid-19 di SMAN 2 Bondowoso. http://repository.unmuhjember.ac.id/11232/ 